Edu Sciences J. Vol. 2, No. 1. March 2021, 62-69

\title{
CAUSALITY ANALYSIS OF CONCEPT UNDERSTANDING WITH CREATIVE THINKING ABILITY OF STUDENT TO SOCIAL CHANGE
}

\author{
Abednego \\ ${ }^{1}$ Faculty of Teacher Training and Educational Sciences, Pattimura University, Maluku- \\ Indonesia
}

*Corresponding Author: abednegodr@gmail.com

\begin{abstract}
Creative thinking develops from students' potential; however, the level of ability to think creatively is different for every human being. Many scientists argue that the higher person's education level will be followed by the ability to think creatively. This statement's emergence stems from the idea that the higher a person's education is because the person receives more education and learning in quantity. From a different perspective, educators worry that the more knowledge a person gets from education and learning is mostly forgotten. It can be believed that not all learning can be understood by students. The conceptual approach applied in learning can help students understand various concepts. The quality of one's understanding can contribute to the ability to think creatively. The purpose of this study was to describe the causal relationship between conceptual understanding and creative thinking skills. The research data were obtained from 38 students through the pre-test and post-test of learning social change. The research data were analyzed using linear regression analysis. The results showed that the contribution of conceptual understanding to thinking creatively was $87 \%$, and other factors influenced the rest. This study concluded that their causal relationship is significant between conceptual understanding and creative thinking skills.
\end{abstract}

Keywords: Understanding concept, Creative Thinking Abilities

\section{Introduction}

The quality of human life is formed from the ability to think creatively obtained from educational events and school management (Hyunjoo Im, Brad Hokanson, \& Kim K. P. Johnson, 2015). The ability to solve life problems is strongly influenced by the ability to think creatively as a skill for life problems experienced (Karpova, Marcketti, \& Barker, 2011). Throughout life a person will never be free from problems, because it is important to practice solving one's own problems. Many people if they experience problems depend on others to solve their life problems and this does not provide opportunities to develop creative thinking skills. Bad habits that afflict most people are always begging for the help of others to solve their life problems. Quality of life is closely related to the ability to think creatively, because it is necessary from an early age to get used to developing creative thinking skills (Hyunjoo Im, Brad Hokanson, and Kim K. P. Johnson, 2015).

Student activities on campus provide wide opportunities for work and working capital is the ability to think creatively (Hyunjoo Im, Brad Hokanson, and Kim K. P. Johnson, 2015). Discussion groups in the classroom where students practice themselves to develop creative thinking skills. It is necessary to build solidarity in discussions in order to establish a good exchange of ideas. If students are not proactive in discussing, it is impossible for their creative thinking skills developing. Knowledge and experience are generally obtained more from the help of others in the form of information sources of knowledge, abilities and experiences. However, if students focus more on memorizing knowledge without understanding the concept of knowledge, this will not be able to develop their creative thinking.

Received December $29^{\text {th }} 2020$, Revision February $10^{\text {th }} 2021$, Accepted for publication February $24^{\text {th }} 2021$

Copyright (C) 2021 Published by FKIP - Unpatti, ISSN 2721-3110 
How important it is to develop creative thinking skills which can only take place through educational settings and classroom learning when providing cultural contexts and social norms that foster creativity. Reflects on this perspective and the emphasis on the interrelationships between creativity of various levels (Hennessey \& Amabile, 2010).

This study focuses more on understanding the concept of social change in order to develop students' creative thinking skills. Methods and conceptual approaches need to be applied through educators and learning, because they condition students to increase their vocabulary for social change and synergistically condition students to develop creative thinking skills (Ilhan Ilter, 2017). Teaching using conventional methods such as lecture method does not condition students to understand concepts. Teaching using conceptual methods and approaches easily conditions understanding of concepts and then develops critical thinking skills, creative thinking skills, decision making, conceptualization, and information processing (Trianggono, 2017)

In the case of conceptual papers, arguments do not originate from data in the traditional sense but involve assimilation and combination of evidence in the form of previously developed concepts and theories (Hirschheim 2008). That is, conceptual papers are not without empirical insights but rather are built on theories and concepts developed and tested through empirical research.

Conceptual papers usually focus on proposing new relationships between constructs; the aim is thus to develop a complete logic and argument about this association to test it empirically (Gilson and Goldberg 2015). The problem of how to develop a logical argument is therefore very important. Apart from arguing that the concepts are interrelated, the author must also provide a theoretical explanation for the link. Because this explanation shows the logic of the relationship between concepts, it is important to build a theory (King and Lepak 2011).

Conceptual change deals with theoretical restructuring, in which children modify their intuitive and synthetic mental models into scientific models (Jing-Wen Lin; MiaoHsuan; Jia-Chi Liang Yuan, 2016). Learning is not about adding new knowledge or filling in incomplete knowledge. Conversely, learning is changing previously misunderstood knowledge into true knowledge through ontological shifts (Harmon, J. M., Hedrick, W. B., \& Wood, K. 2005).

The features in conceptual ecology proposed by Posner et al, are generally recognized as the most influential factors in students' conceptual change (Jing-Wen Lin; Miao-Hsuan; Jia-Chi Liang Yuan, 2016). Conceptual ecological features include (a) anomalies, (b) analogies and metaphors, (c) epistemological commitments, (d) metaphysical beliefs and concepts, and (e) other knowledge (such as knowledge in other fields or competing concepts).

The main objective of vocabulary teaching is to increase students' understanding of the content along with the development of word knowledge, conceptual knowledge, and text. In this regard, studies linking vocabulary learning strategies or skills to students' improvement and acquisition of concept and content knowledge are much more important (Harmon, Hedrick, \& Wood, 2005).

Key words in understanding the concept: identify, explain, translate, interpret, interpret, classify. The revised Bloom's taxonomy provides seven indicators of concept understanding, including: Interpreting, Exemplifying, Classifying, Summarizing, Inferring, Comparing, Explaining. Indicators of understanding the concept will be examined for its relationship with creative thinking skills (Krathwohl, D. R. \& Anderson, L. W. (2001).

Creative thinking can be defined as a whole series of cognitive activities used by individuals according to certain objects, problems and conditions. Individuals who are thinking creatively try to use their imagination, intelligence, insights and ideas when faced with such situations. In addition, trying to suggest an authentic and designing something new, generate different hypotheses, solve problems with the help of finding and finding new applications (Glass, 2004; Young \& Balli, 2014).

Received December $29^{\text {th }} 2020$, Revision February $10^{\text {th }} 2021$, Accepted for publication February $24^{\text {th }} 2021$. Copyright (C) 2021 Published by FKIP - Unpatti, ISSN 2721-3110 
A definition of creativity based on process aspects (Torrance 2008), (1) sensing difficulties, problems, gaps in information, missing elements, something asked; (2) making guesses and formulating hypotheses about these deficiencies; (3) evaluating and testing these guesses and hypotheses; (4) possibly revising and retesting them; and finally (5) communicating the results "This Torrance definition covers the entire creative and scientific process from finding problems to delivering results.

The dimensions of creative thinking as synthesis, articulation and imagination have qualities (Aslan, 2007; Sternberg, 2009), as follows: (1) Synthesis: This dimension includes various activities such as getting benefits from analog thinking, concluding the results original from small parts, presenting new and authentic suggestions for solutions to the problem; (2) Articulation: It involves forming old and new knowledge or expanding current knowledge with the help of new ones, building unusual relationships to come up with authentic solutions and making thoughts concrete with the help of imagination and use of materials; (3) Imagination: This dimension consists of constructing a relationship between valid and reliable thinking, presenting flexible ways of thinking with the help of imagination, to present different insights during the idea production process.

Creative behavior requires a combination of psychological traits that interact as a result of convergent thinking or acquiring knowledge and skill development (Pepkin, 2004),. In a creative person, personal and environmental conditions that provide an opportunity or opportunity to be busy creatively, it is predicted that the product of his creative thinking will emerge. The characteristics of the ability to think creatively (Pepkin, 2004), namely: (1) Skills to think fluently. Come up with many ideas, answers, problem solving and always think of more than one answer; (2) Flexible thinking skills. Can see a problem from different points of view, look for many alternatives or different directions and be able to change the way of thinking; (3) Operational thinking skills. Able to give birth to new and unique expressions, think of unusual ways to express oneself; (4) Detailing skills. Able to enrich and develop an idea or product, be able to add or detail the details of an object, idea or situation so that it becomes more interesting; (5) Appraising skills. Able to make decisions about open situations and not only come up with ideas but also implement them.

\section{Methodology}

\subsection{Sample and Data Collection}

The population of this study were 38 students of the Out-of-School Education Study Program, FKIP Unpatti who offered Urban and Rural Sociology courses, totaling 38 people, then used as research samples.

Coollection data were obtained from: (1) learning outcomes tests through pre-test and post-test to measure understanding of the concept of social change; (2) Discussions were held to measure creative thinking skills with the following items: (a) imaginary goals; (b) think fluently; (c) think flexibly; (d) original thinking; (elaborate thinking).

\subsection{Data Analysis}

Data analysis procedure:

1) Before the research, the instrument validity test and the instrument reliability test were carried out using SPSS 23.00 for windows.

2) Analysis of the difference test between pre-test and post-test, then depicted in graphical form.

3) Data analysis using linear regression techniques, namely analysing the causal relationship of variable $\mathrm{X}$ (ability to understand the concept of social change) with variable Y (Creative Thinking Ability).

Received December $29^{\text {th }} 2020$, Revision February $10^{\text {th }} 2021$, Accepted for publication February $24^{\text {th }} 2021$.

Copyright (C) 2021 Published by FKIP - Unpatti, ISSN 2721-3110 
4) Answering the research hypothesis, namely:

a. The null hypothesis (Ho) is that there is no significant causal relationship between conceptual understanding and the ability to think creatively in students of Nonformal Education Faculty of Teacher Training and Education, Pattimura University.

b. The working hypothesis $(\mathrm{Ha})$ is that there is a significant causal relationship between conceptual understanding and the ability to think creatively in students of Nonformal Education Faculty of Teacher Training and Education, Pattimura University.

\section{Result and Discussion}

At the beginning of the lecture, a pre-test was conducted to measure the conceptual understanding of 38 students and got an average score of 25.21 and at the end of the lecture a post-test was carried out with an average score of 82.70 . Furthermore, increasing understanding of the concept can be seen in Figure 1.

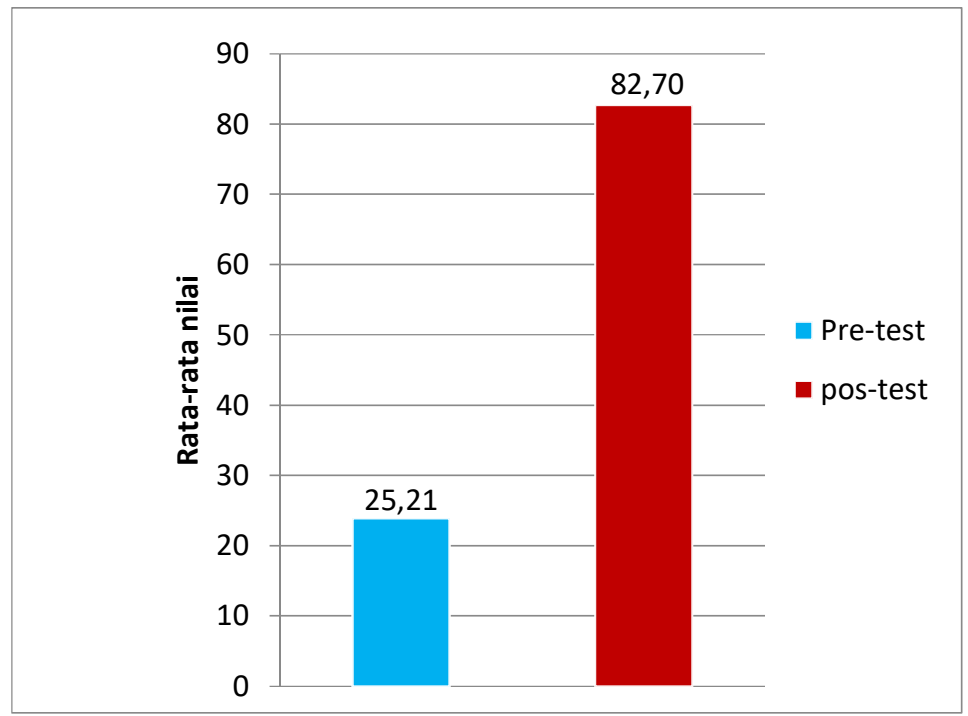

Figure 1. Graph of Improved Concept Understanding

To measure the increase in creative thinking skills of 38 students, a pre-test was carried out and got an average score of 26.84 and at the end of the lecture a post-test was carried out by getting an average value of 83.55. Furthermore, the increase in creative thinking skills can be seen in Figure 2. 


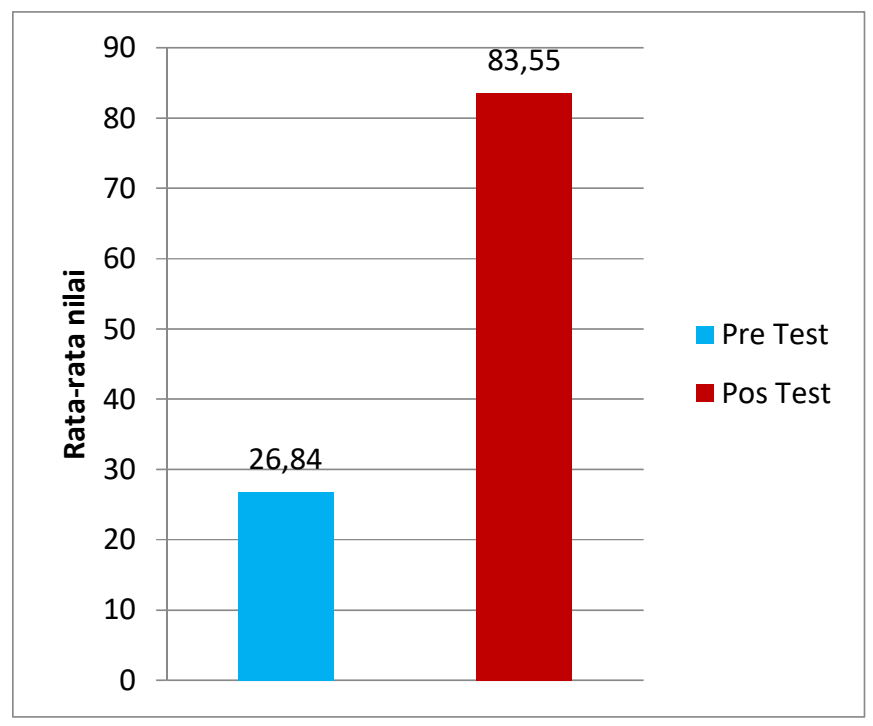

Figure 2. Increased Creative Thinking Ability

Figure 1 above shows an increase in student understanding of concepts through a conceptual approach with a large increase of 82.70 . Figure 2 shows an increase in students' creative thinking skills by 83.55 .

Referring to these data, it can be seen how much improvement between conceptual understanding and creative thinking ability has the same pattern. The same pattern of improvement between the two variables in the test class indicates that there is a causal relationship between conceptual understanding and creative thinking skills.

The data on the increase in the value of concept understanding and creative thinking skills were then analyzed using simple linear regression to see how big the causal relationship between concept understanding and creative thinking skills. Testing simple linear regression analysis using the SPSS 23 application program on the basis of decision making if significance $<0.05$ then variable $\mathrm{X}$ affects variable $\mathrm{Y}$, whereas if significance $>$ 0.05 then variable $\mathrm{X}$ does not affect variable $\mathrm{Y}$. The results of simple linear regression analysis can be seen in table 1 .

Tabel 1. Output Regression Analysis

\begin{tabular}{|l|c|r|r|c|}
\hline \multicolumn{5}{|c|}{ Model Summary } \\
\hline Model & R & R Square & $\begin{array}{c}\text { Adjusted R } \\
\text { Square }\end{array}$ & $\begin{array}{c}\text { Std. Error of } \\
\text { the Estimate }\end{array}$ \\
\hline 1 & $.934^{\mathrm{a}}$ & .872 & .868 & 1.32906 \\
\hline
\end{tabular}

Referring to the results of the analysis, it can be seen that the coefficient of determination (R2) is 0.87 . This means that the contribution of conceptual understanding to the ability to think creatively is $87 \%$ and the rest is influenced by other factors. Based on the partial test, it can be seen that the coefficient value shows a value of 0.93 . This means that every 1 unit increase in conceptual understanding affects the increase in creative thinking skills by 0.93 units. The results of the data analysis described above show that conceptual understanding has a significant causal relationship with the ability to think creatively. To see the significance of variable $\mathrm{X}$ on variable $\mathrm{Y}$, it can be seen in table 2 .

Received December $29^{\text {th }} 2020$, Revision February $10^{\text {th }} 2021$, Accepted for publication February $24^{\text {th }} 2021$

Copyright (C) 2021 Published by FKIP - Unpatti, ISSN 2721-3110 
Table 2. Output Regression Analysis (ANOVA)

\begin{tabular}{|l|l|r|r|r|r|c|}
\hline \multicolumn{2}{|c|}{ MNOVA $^{\mathrm{a}}$} \\
\hline \multirow{3}{*}{ Model } & $\begin{array}{c}\text { Sum of } \\
\text { Squares }\end{array}$ & df & Mean Square & F & Sig. \\
\hline \multirow{3}{*}{1} & Regression & 431.804 & 1 & 431.804 & 244.454 & $.000^{\mathrm{b}}$ \\
\cline { 2 - 8 } & Residual & 63.590 & 36 & 1.766 & & \\
\cline { 2 - 8 } & Total & 495.395 & 37 & & & \\
\hline
\end{tabular}

Referring to the output above, it is known that the value of Fcount is $24.45>$ from Ftable of 3.54 at the 0.01 significance level, so the causality relationship between conceptual understanding and creative thinking ability has a very significant relationship. This research hypothesis test is based on the output in table 3

Table 3. Standardized Output Regression Analysis

\begin{tabular}{|c|c|c|c|c|c|c|}
\hline & \multirow{3}{*}{ Model } & \multicolumn{3}{|c|}{ Coefficients $^{\mathrm{a}}$} & \multirow{3}{*}{$\mathrm{T}$} & \multirow{3}{*}{ Sig. } \\
\hline & & \multicolumn{2}{|c|}{ Unstandardized Coefficients } & \multirow{2}{*}{$\begin{array}{l}\text { Standardized } \\
\text { Coefficients } \\
\text { Beta }\end{array}$} & & \\
\hline & & B & Std. Error & & & \\
\hline \multirow[t]{3}{*}{1} & (Constant) & -20.579 & 6.664 & & -3.088 & .004 \\
\hline & & & & & & \\
\hline & $\mathrm{X}$ & 1.238 & .079 & .934 & 15.635 & .000 \\
\hline
\end{tabular}

\section{Dependent Variable: Y}

The value of $0.05 ; 38$ then we look at the distribution of the $t$ table value, then the $t$ table value is 2.021. Because the $t$ value of 15.63 is greater than $>2.021$, it can be concluded that Ho is rejected and Ha is accepted, which means that:

a. The null hypothesis (Ho) is that there is no significant causal relationship between conceptual understanding and the ability to think creatively in students of Nonformal Education Faculty of Teacher Training and Education, Pattimura University, "rejected".

b. The working hypothesis $(\mathrm{Ha})$ is that there is a significant causal relationship between conceptual understanding and the ability to think creatively in students of Nonformal Education Faculty of Teacher Training and Education, Pattimura University, "be accepted"

\section{Conclusion}

Basically to the results of the analysis above, several conclusions of this study can be stated:

1) Understanding the concept becomes the basis for a person to understand the concept of social change and make connections between concepts in a comprehensive manner.

2) The ability to think creatively plays a role in the systematic thinking of a person in bringing up varied, authentic, and detailed ideas on the concept of social change.

3) There is a significant causality relationship between conceptual understanding and the ability to think creatively.

Received December $29^{\text {th }} 2020$, Revision February $10^{\text {th }} 2021$, Accepted for publication February $24^{\text {th }} 2021$.

Copyright (C) 2021 Published by FKIP - Unpatti, ISSN 2721-3110 


\section{REFERENCES}

Arslan, M. (2007). Ögretim ilke ve yöntemleri. Anı Publishing, Ankara.

Gilson, L. L., \& Goldberg, C. B. (2015). Editors' comment: So, what is a conceptual paper? Group \& Organization Management, 40(2), 127-130.

Gilhooly, K. J., Ball, L. J., \& Macchi, L. (2015) Insight and creative thinking processes: Routine and special. Thinking \& Reasoning, 21(1), 1-4. doi: $10.1080 / 13546783.2014 .966758$

Glass, T. (2004). What gift? The reality of the student who is gifted and talented in public school classrooms. Gifted Child Today, 2(4), 25-29.

Harmon, J. M., Hedrick, W. B., \& Wood, K. (2005). Research on vocabulary instruction in the content- areas: Implications for struggling readers. Reading \& Writing Quarterly, 21, 261-280. http://dx.doi.org/10.1080/10573560590949377

Hennessey, B. A., \& Amabile, T. M. (2010). Creativity. Annual Review of Psychology, 61, $569-598$

Hirschheim, R. (2008). Some guidelines for the critical reviewing of conceptual papers. Journal of the Association for Information Systems, 9(8), 432-441.

Hyunjoo Im, Brad Hokanson, and Kim K. P. Johnson. 2015. Teaching Creative Thinking Skills: A Longitudinal Study. Clothing and Textiles Research Journal 2015, Vol. 33(2) 129-142 a The Author(s) 2015 Reprints and permission: sagepub.com journals Permissions.nav DOI: 10.1177/0887302X15569010 ctr.sagepub.com

Ilhan Ilter. 2017. Concept-Teaching Practices in Social Studies Classrooms: Teacher Support for Enhancing the Development of Students' Vocabulary. DOI

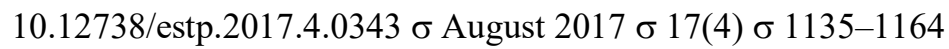

Jing-Wen Lin; Miao-Hsuan; Jia-Chi Liang Yuan.2016. Examining the Factors That Influence Students' Science Learning Processes and Their Learning Outcomes: 30 Years of Conceptual Change Research. Eurasia Journal of Mathematics, Science \& Technology Education, 2016, 12(9), 2617-2646 doi: 10.12973/eurasia.2016.000600a

Karpova, E., Marcketti, S. B., \& Barker, J. (2011). The efficacy of teaching creativity: Assessment of student creative thinking before and after exercises. Clothing and Textiles Research Journal, 29, 52-66.

King, A. W., \& Lepak, D. (2011). Editors' comments: Myth busting - What we hear and what we've learned about AMR. Academy of Management Review, 36(2), $207-$ 214.

Krathwohl, D. R. \& Anderson, L. W. (2001). A Taxonomy for Learning, Teaching, and Assessing: A Revision of Bloom's Taxonomy of Educational Obejctives. New York: Longman

Liu, Z. K., He, J., \& Li, B. (2015). Critical and creative thinking as learning processes at top-ranking Chinese middle schools: possibilities and required improvements. High Ability Studies, 26(1), 139-152. doi: 10.1080/13598139.2015.1015501

Mochammad Maulana Trianggono. 2017. Casualty Analysis Of Concept Understanding With Creative Thinking Abilities Of Student In Physics Problem Solving. Jurnal Pendidikan Fisika dan Keilmuan(JPFK) Avaliable online at http://eJournal.unipma.ac.id/index.php/JPFK Print ISSN: 2442-8868

Pepkin, K. 2004. Creative Problem Solving In Math. Dalam I. K. Mahardika, Maryani, \& S. Murti, Jurnal Pembelajaran Fisika Vol. 1, No. 2, September 2012 (hal. 231232). Jember: FKIP-Universitas Jember.

Sternberg, R. J. (2009). Academic intelligence is not enough WICS: An expended model for effective practice in school and later in life. Retrieved from:

Received December $29^{\text {th }} 2020$, Revision February $10^{\text {th }} 2021$, Accepted for publication February $24^{\text {th }} 2021$.

Copyright (C) 2021 Published by FKIP - Unpatti, ISSN 2721-3110 
https://www.clarku.edu/research/mosakowskiinstitute/conferences/mar12/paper $s /$ Sternberg.

Torrance. 2008. Torrance Test of Creative Thinking: The question of its construct validity. Article in Thinking Skills and Creativity · April 2008 DOI: 10.1016/j.tsc.2008.03.003

Young, M. H. \& Balli, S. J. (2014). Gifted and talented education: student and parent perspectives. Gifted Child Today, 37(4), 236-246. doi:10.1177/10762175145.

Received December $29^{\text {th }} 2020$, Revision February $10^{\text {th }} 2021$, Accepted for publication February $24^{\text {th }} 2021$

Copyright (C) 2021 Published by FKIP - Unpatti, ISSN 2721-3110 